\title{
TEORI EVOLUSI MANUSIA DALAM PERSPEKTIF AL-QUR'AN
}

\author{
Oleh: Aas Siti Sholichah ${ }^{1}$
}

\begin{abstract}
This paper will analyze the theory of human evolution that developed in the West and the theory of human evolution that is explained in the Qur'an with the interpretation approach. The method used in this paper is to use qualitative methods derived from sharing books relating to the above problems. The approach to the interpretation method of the Qur'an uses the thematic method, because this method can study contemporary problems. The theory of evolution began to be studied and debated in the 6th century BC, beginning with the Greek philosopher Anaximander, Empedocles, Lucretius, the same opinion was expressed by Arab biologist Al Jahiz, Persian philosopher Ibn Miskawaih, Ikhwan As-Shafa, and Chinese philosopher Zhuangzi. Furthermore, the theory of evolution was published by a British scientist named Charles Darwin, the results of his research on evolution, especially human evolution, explained that the theory of evolution was not created by God but stood alone. This opinion caused debate among scientists and religious leaders especially Islam was rejected because it contradicted the Qur'an.
\end{abstract}

Keywords: Human, Theory of Evolution, Al-Qur'an

Abstrak: Tulisan ini akan menganalisa mengenai teori evolusi manusia yang berkembang di Barat dan teori evolusi manusia yang dijelaskan dalam Al-Qur'an dengan pendekatan tafsir. Metode yang digunakan dalam penulisan ini adalah menggunakan metode kualitatif yang bersumber dari berbagi buku yang berkaitan dengan permasalahan di atas. Adapun pendekatan metode penafsiran Al-Qur'an menggunakan metode tematik, karena metode ini dapat mengkaji problem kontemporer. Teori evolusi mulai menjadi kajian dan perdebatan pada abad 6 SM, Diwali oleh seorang filsuf Yunani Anaximander, Empedocles, Lucretius, pendapat sama juga disampaikan oleh biologiawan Arab Al Jahiz, filsuf Persia Ibnu Miskawaih, Ikhwan As-Shafa, dan filsuf Cina Zhuangzi. Selanjutnya teori evolusi dipublikasikan oleh ilmuan Inggris bernama Charles Darwin, hasil penelitiannya mengenai evolusi terutama evolusi manusia menjelaskan

${ }^{1}$ Aas Siti Sholichah, Dosen Institut Perguruan Tinggi Ilmu Al-Qur'an (PTIQ) Jakarta. Email: shalichah@gmail.com

109| Aas Siti Sholichah 
bahwa teori evolusi tidak diciptakan Tuhan akan tetapi berdiri sendiri. Pendapat tersebut menimbulkan perdebatan dikalangan para ilmuan dan agamawan terutama Islam ditolak karena bertentangan dengan Al-Qur'an.

Kata kunci: Manusia, Teori Evolusi, Al-Qur'an.

\section{A. Pendahuluan}

Evolusi merupakan cabang sains biologi yang menjelaskan mengenai proses perkembangan dan perubahan makhluk hidup baik secara genetik maupun organik. Kemunculan teori evolusi pada awalnya tepatnya pada fase fixisme tidak dipersoalkan dan tidak menimbulkan berbagai perdebatan, baik dikalangan ilmuan maupun kalangan agamawan. Perdebatan mulai hadir ketika seorang ilmuan berkebangsaan Inggris Charles Darwin, mempublikasikan hasil penelitiannya mengenai spesies makhluk hidup yang menjelaskan bahwa spesies makhluk hidup tidak diciptakan secara terpisah oleh Tuhan tetapi diciptakan berdasarkan dari nenek moyang yang sama dan menjadi berbeda satu sama lain akibat seleksi alam. Penemuan dan penelitian tersebut menimbulkan kontradiktif baik dikalangan ilmuan maupun dikalangan agamawan. Teori evolusi Charles Darwin menganggap manusia berasal dari Sinpanse (kera), pernyataan tersebut yang memicu pro kontra, sehingga karena teori evolusi seleksi alam Charles Darwin mayoritas manusia menyamakannya dengan teori evolusi yang lain. Hal ini mengakibatkan ketidakpercayaan dan keraguan terhadap teori evolusi yang sudah berkembang.

Menjelang abad ke 20, perdebatan teori evolusi seleksi alam mengalami titik terang dengan berkembangnya ilmu genetika yang menemukan struktur molekul DNA oleh ahli Botani dari Austria Gregor Mendelan pada tahun 1865. Pada tahun 1950 setelah ditemukan struktur gen dan kromosom menguatkan penemuan struktur molekul DNA (Deoxyribonucleic Acid) yang berisi informasi genetik meragukan teori evolusi seleksi alamnya Charles Darwin dengan alasan kerumitan yang luar biasa dari kehidupan untuk berubah menjadi species baru dan ketidakabsahan mekanisme evolusi yang diajukan Charles Darwin.

Artikel ini akan menjelaskan mengenai teori evolusi manusia baik berdasakan sejarah dan perkembangannya, Untuk mendapatkan pejelasan yang terperinci dan benar, tulisan ini akan mengurai teori evolusi manusia baik berdasarkan ilmu pengetahuan dan perspektif Al-Qur'an, dengan harapan tulisan ini dapat berguna untuk ilmu pengetahuan. 


\section{B. Konsep Teori Evolusi Manusia}

\section{Diskursus Teori Evolusi}

Teori merupakan pengetahuan ilmiah mencakup penjelasan mengenai suatu sektor tertentu dari disiplin ilmu dan dianggap benar ${ }^{2}$ berdasarkan hasil pengamatan, penelitaian yang mendalam mengenai disiplin ilmu tertentu.Menurut Kerlinger teori adalah suatu himpunan dari konstrukkonstruk (konsep-konsep), definisi-definisi dan proposisi-proposisi yang saling berkaitan dan menyatakan suatu pandangan yang sistematis tentang suatu fenomena dengan cara menentukan hubungan antarvariabel, dengan tujuan menjelaskan fenomena tersebut. ${ }^{3}$ Oxford Advanced Learner's Dictionary menjelaskan teori adalah suatu himpunan gagasan yang masuk akal dan bertujuan untuk menjelaskan fakta-fakta atau kejadian-kejadian. ${ }^{4}$

Sedangkan kata evolusi berasal dar bahasa Latin "evolvere" artinya berkembang, mekar. Jadi evolusi adalah perkembangan yang maju dan meningkat setapak demi setapak dan tidak mendadak. ${ }^{5}$

Menurut biologi atau organik evolusi adalah proses perkembangan segala bentuk kehidupan atau perkembangan tahap demi tahap yang dilawan dengan tidak adanya perubahan sama sekali, atau perubahan yang menjebatani kesenjangan. ${ }^{6}$

Secara sederhana, teori evolusi dapat didefinisikan sebagai himpunan gagasan atau pendapat yang menjelaskan tentang proses kejadian tentang fenomena yang lambat laun mengalami perkembangan dan perubahan dalam bentuk dan fungsi.

${ }^{2}$ Teori terdiri dari hukum-hukum atau statement yang menjelaskan hubungan antar yang variabel. Teori bersifat universal dan memiliki tingkat keumuman yang tinggi berfungsi sebagai teori ilmiah. Syarat teori adalah, pertama, konsisten dengan teori sebelumnya, kedua, Sesuai dengan data empiris, ketiga Mengganti teori lama yang tidak cocok dengan pengujian empiris dan fakta. Suwardi Endaswara, Filsafat Ilmu: Konsep, Sejarah dan Pengembangan Metode Ilmiah, Yogyakarta: Capas, 2012, hal. 8.

${ }^{3}$ Suyono dan Hariyanto, Belajar dan Pembelajaran: Teori dan Konsep Dasar, Bandung: Remaja Rosdakarya, 2017, cet-3, hal. 27.

${ }^{4}$ Teori adalah pernyataan tentang prinsip-prinsip yang berlaku bagi subjek bahasan tertentu. Suyono dan Hariyanto, Belajar dan Pembelajaran: Teori dan Konsep Dasar, Bandung: Remaja Rosdakarya, 2017, cet-3, hal. 27.

${ }^{5}$ Dick Hartono, Kamus Populer Fisafat, Jakarta: Rajawali, 1986 hal. 25.

${ }^{6}$ Dalam pandangan organik atau biologi kehidupan yang ada saat ini adalah berasal dari kehidupan sebelumnya yang mengalami perkembangan dan perubahan dan perbedaan bentuk, dan tipe. Ismet Junus, Memahai Manusia dalam Bingkai Pelangi Filsafat, Medan: Fakultas Psikologi Universitas Medan, 2010, Cet-2, hal. 56. 


\section{Hakikat Manusia}

Manusia menurut kamus bahasa Indonesia adalah "makhluk yang berakal, berbudi (mampu menguasai makhluk lain)". ${ }^{7}$ Dari pengertian ini, manusia merupakan makhluk Allah SWT yang diberikan potensi akal fikiran dan budi, moral dan nalar untuk dapat menguasai makhluk lain demi tercapainya kehidupan yang makmur dan maslahat.

Sedangkan dalan bahasa arab, kata manusia disepadankan dengan kata nas, basyar, insan, mar'u dan ins. ${ }^{8}$ Meskipun bersinonim, namun katakata tersebut mengandung makna yang spesifik. Sedangkan dalam pandangan ilmu pengetahuan, manusia memiliki beberapa pendapat dan argumen yang disesuaikan dengan metodologi yang dikembangkan. Penganut teori behaviorisme berpendapat bahwa manusia sebagai homo mehanibcus (manusia mesin). Dasar pemikiran ini bahwa segala tingkah laku manusia terbentuk sebagai proses belajar manusia terhadap lingkungan. Sedangkan penganut teori psikoanalisis berpendapat bahwa manusia merupakan makhluk yang memiliki perilaku interaksi antara komponen biologis $(i d)$, psikologis (ego), dan social (superego).

Id merupakan pembawaan sifat fisik biologis sejak lahir dan menjadi sumber energi yang memberikan kekuatan terhadap ego dan superego. Ego adalah lingkup rasional yang berupaya menjinakkan keinginan dari $i d$, dimana ego berupaya mengatur hubungan antara keinginan subjektif individual dan tuntunan objektif realitas sosial. Sedangkan superego berfungsi sebagai aspek moral dalam kepribadian dan selalu mengingatkan ego agar senantiasa menjalankan fungsinya sebagai pengontrol $i d .{ }^{9}$

Sedangkan manusia dalam pandangan teori kognitif berpendapat bahwa manusia adalah homo sapiens yaitu manusia sebagai makhluk yang bereaksi secara aktif dengan lingkungannya karena manusia merupakan makhluk yang berfikir.

Jika melihat hakikat manusia berdasarkan dari berbagai pandangan dan disiplin ilmu, maka manusia dapat dikategorikan dalam bentuk tipe manusia sebagai berikut:

1. Tipe manusia politik memandang dunia sebagai arena perebutan kekuasaan, persepsinya menang-kalah, menang artinya yang memegang kekuasaan dan kalah adalah yang dikuasai.

2. Tipe manusia ilmuwan, memandang manusia sebagai wacana penelitian dan diskusi keilmuan. Persepsinya benar-salah, benar

${ }^{7}$ Usman A. Hakim, Kamus Bahasa Indonesia, Jakarta: Balai Pustaka, 2001, hal. 212.

${ }^{8}$ Abdullah bin Nuh, Kamus Indonesia Arab, Jakarta: Mutiara, 2008, hal. 135.

${ }^{9}$ Nasaruddin Umar, ArgumenKesetaraan Gender Perspektif Al-Qur'an, Jakarta: Paramadina,2001, hal. 46. 
artinya sesuai pikiran dan kenyataan, dan salah artinya tidak sesuainya pikiran dan kenyataan.

3. Tipe manusia bisnis, memandang dunia sebagai arena mencari laba, persepsinya laba-rugi, laba artinya keberhasilan dan rugi kegagalan.

4. Tipe manusia rohaniawan, memandang dunia sebagai arena mencari kebaikan, persepsinya baik-buruk, baik artinya tidak sesuainya hati nurani dengan kenyataan.

5. Tipe manusia biasa, memandang dunia sebagai arena mencari pekerjaan, persepsinya upah layak dan upah tidak layak, upah layak artinya bisa hidup layak sebagai manusia, dan upah tidak layak artinya kemiskinan, penderitaan dan kesengsaraan. ${ }^{10}$

6. Tipe manusia artis, memandang dunia sebagai arena indah dan jelek, artinya indah artinya baik jika dipandang oleh mata. ${ }^{11}$

Dari berbagai tipe yang dikemukakan di atas, hal ini menggambarkan manusia memiliki potensi yang luar biasa yang dapat dikembangkan dalam mengelola alam raya dan menciptakan kemampuan dan potensi berdasarkan ilmu pengetahuan dan lingkungan dimana manusia berada.

\section{Hakikat Manusia dalam Perspektif Al-Qur'an}

Dari berbagai pendapat di atas, pandangan manusia disempurnakan oleh pendapat Al-Qur'an yang menjelaskan bahwa manusia merupakan makhluk mulia dan sempurna, hal ini disebabkan manusia diberikan potensi akal pikiran, dengan akal pikiran tersebut manusia dapat berfikir dan membedakan mana yang baik dan mana yang buruk. Selain dibekali akal pikiran manusia diberikan potensi nafsu, dengan potensi nafsu jika tidak dimanfaatkan dengan baik maka akan menciptakan kejelekan, isyarat potensi kebaikan dan keburukan dalam diri manusia dijelaskan dalam Al-Qur'an asySyams/91: 7-8:

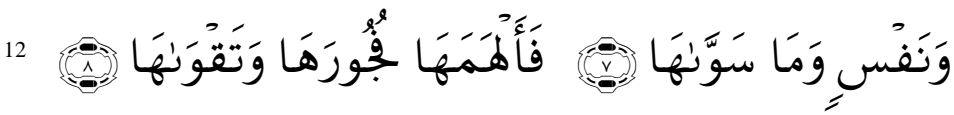

${ }^{10}$ Tjatjuk Siswandoko Darsono, Manajemen Sumber Daya Manusia abad 21, Jakarta: Nusantara Consulting, 2011, hal. 20.

${ }^{11}$ Darwis Hude, disampaikan padadiskusi kelas pasca sarjana mengenai Sumber Daya Manusia pandangan Islam, Jakarta: PTIQ 21 Februari 2016.

${ }^{12}$ Dan jiwa serta penyempurnaannya (ciptaannya). Maka Allah mengilhamkan kepada jiwa itu (jalan) kefasikan dan ketakwaannya. 
"Dan jiwa serta penyempurnaannya (ciptaannya), Maka Allah mengilhamkan kepada jiwa itu (jalan) kefasikan dan ketakwaannya.

Dari penjelasan ayat Al-Quran tersebut, dapat dijelaskan bahwa setiap manusia mempunyai potensi baik (taqwa), dan buruk (fujur). Potensi tersebut merupakan indikator kualitas manusia, tergantung manusia mengelola, jika potensi kebaikan yang dikembangkan maka manusia berpotensi menjadi manusia yamg bertaqwa, namun jika potensi kejahatan yang dikembangkan, manusia berpotensi menjadi jahat dan kelam. ${ }^{13}$

Manusia merupakan makhluk Allah yang diciptakan sempurna dibandingkan dengan makhluk lain yang ada di bumi ini. kesempurnaan dan keistimewaan manusia tersebut merupakan karunia yang telah Allah berikan melalui potensi jasmaniah (tubuh), ruhaniah (spiritual), nafsiyah (jiwa) dan aqliyah (pikiran) ${ }^{14}$, potensi tersebut yang dapat menghantarkan manusia sebagai makhluk berakal dan berfikir.

Dengan dibekali akal fikiran, manusia dapat berilmu pengetahuan yang dapat menciptakan sesuatu yang baru dan bermanfaat dan dengan dibekali akal fikiran manusia mampu berkomunikasi antara yang satu dengan yang lain dan dengan perkembangan dan kemajuan komunikasi dan pengetahuan manusia modern dapat menciptakan teknologi, sehingga perkembangan ilmu pengetahuan dan teknologi tersebut dapat dimanfaatkan dan dipergunakan untuk kehidupan manusia dan makhluk lainnya di bumi.

Untuk dapat mengembangkan diri dan melakukan peranannya baik secara sosial maupun pribadi, Allah SWT memberikan potensi manusia meliputi jasmaniah (tubuh), ruhaniah (spiritual), nafsiyah (jiwa) dan aqliyah (pikiran) ${ }^{15}$. Dengan berbekal potensi tersebut manusia akan mendapatkan eksistensinya sebagai makhluk berfikir sebagai anugerah dari Allah SWT.

Al-Qur'an sangat menjunjung tinggi nilai-nilai yang terkandung dalam pribadi setiap manusia. Isyarat yang memberikan manusia mendapatkan peluang makhluk yang sempurna tertuang dalam ayat-ayat AlQur'an dengan menggunakan istilah khalifah fil ardh.

Khalifah fil Ardh dapat diartikan sebagai pemimpin di muka bumi. Proses penciptaan manusia menjadi pemimpin di bumi ini diawali dengan keberadaan Nabi Adam. Untuk dapat bertahan dan memiliki tingkat berfikir Allah memberikan ilmu dan pemahaman kepada Nabi Adam dalam kitab suci Al-Qur'an surat al-Baqarah/2: 30-37.

13 Hamka Abdul Aziz, Pendidikan Karakter Berpusat pada Hati, Jakarta: AlMawardi, 2012, hal. 41.

${ }^{14}$ Umiarso, Zamroni, Pendidikan Pembebasan Dalam Perspektif Barat dan Timur, Jakarta: Ar-Ruz Media, 2011 hal.7

${ }^{15}$ Umiarso, Zamroni, Pendidikan Pembebasan Dalam Perspektif Barat dan Timur, Jakarta: Ar-Ruz Media, 2011 hal.7 
Kandungan surat Al-Baqarah ayat 30-37 tersebut merupakan rangkaian kisah yang merefleksikan keterpaduan unsur-unsur kecerdasan spiritual, kecerdasan emosi, kecerdasan intelektual, serta digambarkan suasana konflik, tipu daya dan makar musuh yaitu kekalahan sementara akal melawan hawa nafsu. ${ }^{16}$

Potensi dan tanggung jawab manusia sebagai khalifah fil al-ardh merupakan bentuk penghargaan Allah SWT yang diberikan kepada manusia, sehingga dengan fungsi tersebut manusia menjadi makhluk yang terhormat, dan diberikan keleluasaan untuk mengelola alam ini secara gratis. Untuk itu agar potensi tersebut menjadi bermanfaat dan dipergunakan secara maksimal, Kualitas manusia tersebut dapat dijabarkan sebagai berikut: ${ }^{17}$

1. Kualitas Jasmani

Manusia merupakan satu kesatuan yang terdiri dari substansi yaitu tubuh dan jiwa, jasmani atau tubuh adalah sesuatu yang konkrit yang dapat dipelajari secara realistik, sedang jiwa yang abstrak hanya dapat dipelajari melalui gejala-gejala yang ditampilkan melalui sikap dan perilaku.

2. Kualitas Psikologis

Kualitas psikologi merupakan kualitas yang abstrak. Kualitas psikologi diukur dari tingkat pengembangan dan pendayagunaan potensi-potensi yang terdapat di dalam, seperti bakat minat, kemampuan berfikir, kepedulian sosial dan kepekaan emosi.

3. Kualitas sebagai makhluk sosial

Kualitas ini bersumber dari substansi psikologi sebagai energi penggerak manusia, baik berupa gerak fisik maupn gerak non fisik. Perwujudan dari kualitas ini adalah mampu bergaul dan memiliki kepekaan dan kepedulian sosial yang tinggi yang dapat ditampilkan melalui perilaku yang baik sebagai anggota masyarakat.

4. Kualitas Kemandirian

Kemandirian merupakan sikap dan perilaku yang dapat mengantarkan manusia pada kesuksesan dalam menjalankan kehidupan. Kemandirian merupakan totalitas kepribadian yang harus dimiliki sebagai sumber daya manusia. Karakteristik manusia berkualitas adalah seseorang yang memiliki kepribadian mandiri dengan sikap rajin bekerja, sanggup bekerja keras, tekun gigih disiplin mampu bersaing dan dapat bekerja sama.

5. Kualitas Iman dan Taqwa

${ }^{16}$ Dedhi Suharto, Qur'anic Intelligence Quotient (membangun kecerdasan AlQur'an), Tangerang: FBA Press, hal. xix

${ }^{17}$ Hadari Nawawi, Mimi Martini, Manusia Berkualitas, Yogyakarta: Gajah Mada University Press, 1994, hal. 48-61. 
Kualitas Iman dan taqwa adalah dapat mewujudkan kehidupan dengan sukses secara spiritual, yaitu dengan cara menggunakan segala potensi yang telah diciptakan Allah SWT.

Selain itu, sebagai makhluk Allah SWT manusia diberikan keleluasaan untuk mengelola alam raya ini, untuk mengelola alam ini Allah telah anugerahkan manusia dengan ilmu pengetahuan sebagai panduan kehidupan, isyarat tersebut tertuang dalam Al-Qur'an surat al-Isra/17: 70 sebagai berikut,

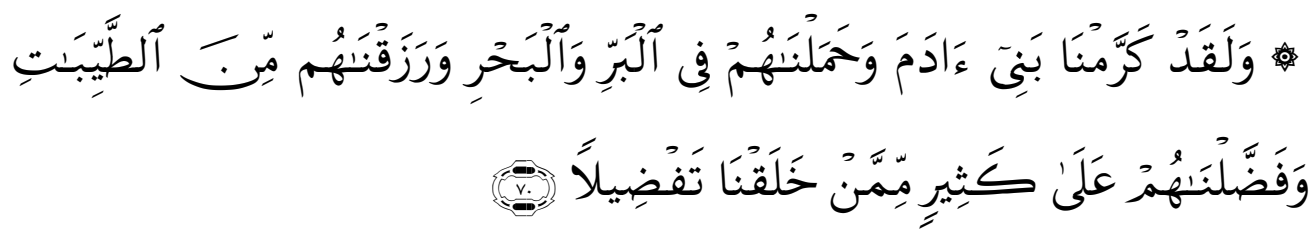

Dan sesungguhnya telah Kami muliakan anak-anak Adam, Kami angkat mereka di daratan dan di lautan, Kami beri mereka rezeki dari yang baik-baik dan Kami lebihkan mereka dengan kelebihan yang sempurna atas kebanyakan makhluk yang telah Kami ciptakan.

Menurut Al-Khazin, Allah memuliakan manusia dari semua makhluk yang ada di alam raya ini yang bersifat fundamental secara alamiah, seperti potensi akal pikiran, verbal, grafis, dan bentuk yang serba seimbang, dengan penganugerahan potensi tersebutmanusia mampu mengubah dan mengembangkan budaya secara progresif sejalan dengan kebutuhan dan dinamika kehidupan dan lingkungan manusia. ${ }^{18}$

Al-Zamakhsyari, seorang ahli tafsir klasik, berpendapat bahwa kemuliaan yang diberikan Allah kepada manusia dalam ayat di atas adalah penganugerahan akal yang digunakan untuk berfikir, berkreasi, sekaligus membedakan antara baik dan buruk. Kemuliaan tersebut menjadi modal bagi manusia untuk mengelola dan menundukkan potensi bumi. Kekuatan akal inilah yang membedakan antara manusia dengan makhluk lainnya. ${ }^{19}$

Isyarat mengenai kepemimpinan manusia dalam kehidupan ini pun dijelaskan dalam sebuah hadits sebagai berikut:

Ketahuilah, bahwa kamu sekalian adalah sebagai pemimpin, dan sekalian bertanggung jawab terhadap pimpinannya (rakyatnya), maka sebagai amir (pemimpin) yang memimpin manusia yang banyak adalah sebagai pemimpin 2013, hal. 50

${ }^{18}$ Al-Khazin, disarikan oleh Darwis Hude, Logika Al-Qur'an, Jakarta: Eurobia,

19 Al-Imam Abu al-Qasim Jarullah Mahmud bin 'Umar al-Zamakhsyari, alKasysyaf 'an Haqaiq al-Tanzil wa al- 'Uyun al-Aqawil fi wujuh al-Ta'wil, Beirut : Dar alKitab al-'Arabi, tth, Jilid 2, hal. 653. 
yang bertanggung jawab atas pimpinannya (rakyatnya), dan seorang suami (lelaki) adalah sebagai pemimpin bagi keluarganya dan ia bertanggung jawab terhadap mereka. Seorang istri adalah pemimpin di rumah suaminya serta terhadap anak-anaknya yang ia bertanggung jawab terhadap mereka. Dan seorang hamba (budak) adalah sebagai pemimpin dalam menjaga harta tuannya dan ia bertanggung jawab terhadap tuannya. Ketahuilah, kamu sekalian adalah pemimpin dan kamu sekalian bertanggung jawab terhadap pimpinanya (HR. Muslim) ${ }^{20}$

Dari penjelasan hadits tersebut dijelaskan bahwa masing-masing manusia adalah pemimpin untuk dirinya sendiri, dan setiap pemimpin akan bertanggung jawab atas apa yang dipimpinnya. Dalam hadits tersebut juga dijelaskan kepemimpinan dalam lembaga yaitu rumah tangga dan Negara yang semua itu akan dimintai pertanggungan jawabnya kelak di hadapan Allah SWT.

Dengan kualitas kepemimpinan yang dimiliki, manusia dapat menjadi makhluk yang dapat mengelola alam ini dengan baik dan dapat menciptakan inovasi-inovasi dalam kehidupan.

Kemajuan ilmu pengetahuan dan teknologi yang saat ini dirasakan merupakan bukti bahwa sumber daya manusia memiliki peranan yang penting dalam kehidupan ini.

Jika diamati dari sejarah awal manusia ada, kehidupan manusia sangat sederhana, manusia menjadi makhluk yang berpindah-pindah dari tempat satu ke tempat yang lain, untuk mencukupi kebutuhan diri sendiri dan keluarga, manusia berburu dan berpindah-pindah tempat, kegiatan berburu rupanya tidak bisa bertahan lama, agar dapat bertahan hidup manusia mulai melakukan perubahan pola kerja dan pola hidup dengan cara bercocok tanam atau disebut masa agraris.

Kehidupan agraris semakin berkembang seiring dengan kemajaun teknologi dimana terciptanya mesin-mesin penumbuk padi membuat manusia semakin canggih dan beralih kepada masa industri dan teknologi.

Manusia yang ada di alam raya ini dapat menikmati dan merasakan kemajuan ilmu pengetahuan, industridan teknologi merupakan sarana yang mudah untuk melakukan pekerjaan, transaksi, transportasi dan komunikasi. Hari ini terjadi peristiwa di belahan dunia lain, saat itu pula dapat diakses informasi melalui media televisi dan internet.

Kecanggihan ilmu pengetahuan manusia juga menghantarkan manusia pada masa dimana komunikasi dan informasi begitu mudah. Banyak cara yang dapat dilakukan untuk berkomunikasi, jika dahulu surat

${ }^{20}$ Lihat Husei Bahreisj, Himpunan Hadits Shahih Muslim, Surabaya: Al-Ikhlas, 1987, hal. 244-245. 
merupakan alat komunikasi yang efektif, maka saat ini media-media lain dapat menjadi alat komunikasi seperti handphone, tablet, telepon, dan internet, semua itu merupakan bukti dari kemajuan ilmu pengetahuan dan teknologi yang dirancang yang berasal dari sumber daya manusia.

Untuk itu sebagai makhluk dinamis, manusia harus terus berusaha dan bekerja secara profesional dalam mengemban tugas mulia sebagai khalifah, untuk dapat bekerja dan berusaha dengan baik dan profesional, Allah telah mengingatkan dalam Al-Qur'an Surat at-Taubah/9: 105 sebagai berikut:

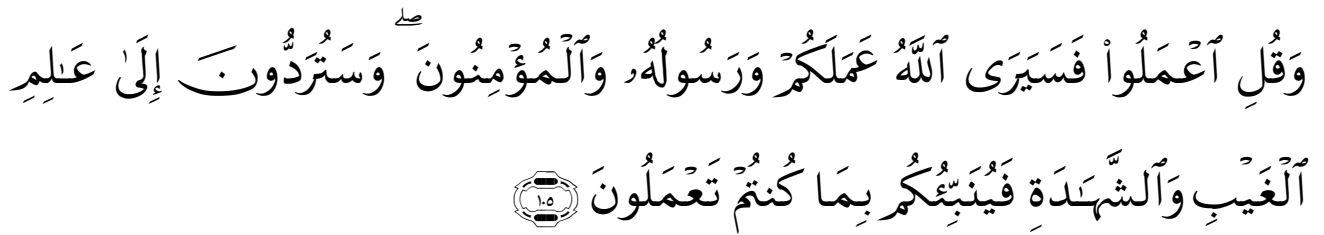

Dan Katakanlah: "Bekerjalah kamu, maka Allah dan Rasul-Nya serta orangorang mukmin akan melihat pekerjaanmu itu, dan kamu akan dikembalikan kepada (Allah) Yang Mengetahui akan yang ghaib dan yang nyata, lalu diberitakan-Nya kepada kamu apa yang telah kamu kerjakan.

Kandungan ayat tersebut mengisyaratkan kepada manusia hendaklah bekerja dengan baik dan profesional, karena apa yang dikerjakan oleh manusia akan dilihat oleh Allah dan Rasul serta akan dimintai pertanggung jawaban dan dengan bekerja yang sungguh-sungguh akan mendapatkan hasil yang maksimal.

Dengan dibekali akal fikiran, manusia dapat berilmu pengetahuan yang dapat menciptakan sesuatu yang baru dan bermanfaat dan dengan dibekali akal fikiran manusia mampu berkomunikasi antara yang satu dengan yang lain dan dengan perkembangan dan kemajuan komunikasi dan pengetahuan manusia modern dapat menciptakan teknologi, sehingga perkembangan ilmu pengetahuan dan teknologi tersebut dapat dimanfaatkan dan dipergunakan untuk kehidupan manusia dan makhluk lainnya di bumi.

Al-Qur'an sangat menjunjung tinggi nilai-nilai yang terkandung dalam pribadi setiap manusia. Isyarat yang memberikan manusia mendapatkan peluang makhluk yang sempurna tertuang dalam ayat-ayat AlQur'an dengan menggunakan istilahan-naas, insan, basyar. ${ }^{21}$

1. An-Naas

${ }^{21}$ Hamka Abdullah Aziz, Pendidikan Karakter Berpusat pada Hati, Jakarta: AlMawardi, 2012, hal. 26-30. 
Kata an- Nas menurut al-Qur'an bermakna eksistensi manusia sebagai makhluk sosial dan sebagai makhluk hidup keturunan nabi Adam. Dalam al-Qur'an kata an- Nasdisebutkan sebanyak 240 kali dalam 53 surat. $^{22}$

Manusia sebagai an- Nasdigunakan al- Qur'an untuk menjelaskan bahwa manusia merupakan makhluk sosial yang tidak dapat hidup tanpa bantuan manusia lain, untuk itu manusia mengembangkan berbagai aktifitas untuk meningkatkan kualitas kehidupannya. Isyarat mengenai makna manusia sebagai an- Nastertera dalam al-Qur'an surat al- Hujurat/49: 13 sebagai berikut,

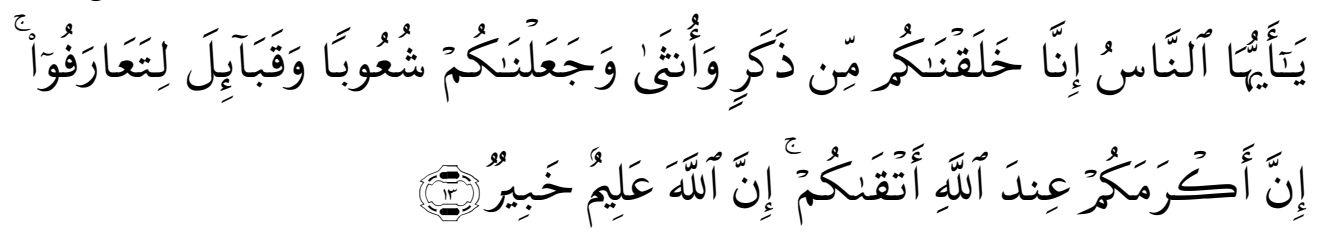

Hai manusia, sesungguhnya Kami menciptakan kamu dari seorang laki-laki dan seorang perempuan dan menjadikan kamu berbangsa-bangsa dan bersuku-suku supaya kamu saling kenal-mengenal. Sesungguhnya orang yang paling mulia diantara kamu disisi Allah ialah orang yang paling takwa diantara kamu. Sesungguhnya Allah Maha Mengetahui lagi Maha Mengenal.

Ayat ini diturunkan berkenaan dengan perintah Rasulullah SAW memerintahkan Bani Bayadhah untuk menikahkan Abu Hindun dengan seorang perempuan dari kalangan mereka yaitu hamba sahaya. Pendapat lain menjelaskan bahwa ayat ini turun tentang Tsabit bi Qais bin Syamas dan ucapannya yang tidak memberikan tempat pada dirinya, Tsabit melihat ada yang merah, hitam dan putih, Rasulullah bersabda sesungguhnya engkau tidak dapat mengungguli mereka kecuali ketakwaannya. ${ }^{23}$

Dari tafsir ayat tersebut dijelaskan manusia merupakan ciptaan Allah SWT yang diciptakan bersuku-suku, berbangsa-bangsa tujuannya untuk saling mengenal antar manusia yang satu dengan yang lainnya, sehingga dengan mengenal tersebut manusia saling berinteraksi dan saling melengkapi juga saling membutuhkan, serta bekerjasama dalam berbagai kebutuhan hidup, dan dalam tafsir ayat ini dijelaskan bahwa tidak diperkenankan untuk menghina dan tidak menghargai sesama manusia, karena yang menjadi penilaian di hadapan Allah SWT bukan fisik dan kecerdasan, namun ketakwaannya.

${ }^{22}$ Quraish Shihab, Wawasan Al-Qur'an Tafsir Maudu'I atas Berbagai Persoalan Umat, Bandung: Mizan, 1998, hal. 281.

${ }^{23}$ Syaikh Imam Qurthubi, Tafsir Al-Qurtubi Akhmad Khatib (penerjemah), judul asli Al-Jami' li Ahkaam Al-Qur'an, Jakarta: Pustaka Azzam, 2009, hal. 101-102. 


\section{Al- Insan}

Dalam Al- Qur'an, manusia juga disebut al- Insan. Secara etimologi al- Insan bermakna harmonis, lemah lembut dan pelupa. Dalam al- Qur'an kata al- Insan disebutkan sebanyak 73 kali dan tersebar dalam 43 surat. $^{24}$

Manusia jika dilihat dari struktur lahir dan bathin memiliki panca indra, otak dan hati yang sempurna. Potensi yang ada dalam diri manusia tersebut merupakan karunia dari Allah SWT yang diberikan hanya kepada manusia, untuk itu jika potensi tersebut dikembangkan dan digunakan ke arah yang baik maka akan menjadi baik, namun jika potensi tersebut dipergunakan ke arah yang tidak baik maka akan menghasilkan keburukan. Isyarat mengenai al-Insan tersebut dijelaskan dalam al- Qur'an surat atTiin/95: 4-5 sebagai berikut,

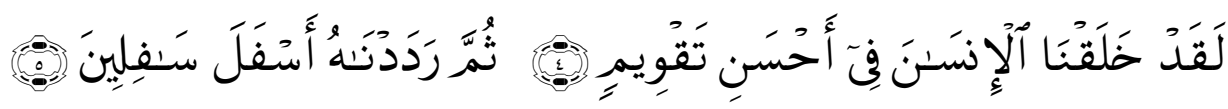

Sesungguhnya Kami telah menciptakan manusia dalam bentuk yang sebaikbaiknya. Kemudian Kami kembalikan dia ke tempat yang serendahrendahnya (neraka).

Jalaluddin Rahmat menjelaskan kata al-Insan dengan tiga kategori, pertama, manusia sebagai khalifah dan pemikul amanah, kedua manusia predisposisi negatif pada diri manusia, ketiga manusia berhubungan dengan potensi manusia. ${ }^{25}$

Jika dilihat dari penjelasan di atas, kata al-Insan dapat dijelaskan mengenai proses kejadian manusia secara dinamis dan sempurna, yaitu manusia yang mempunyai tanggung jawab untuk menjadi pemimpin, baik pemimpin untuk diri sendiri, keluarga dan masyarakat, serta fungsi manusia sebagai pelengkap manusia lain, sehingga antara manusia yang satu dengan yang lain dapat bekerja sama untuk saling melengkapi dan memperbaiki diri, potensi manusia juga memiliki potensi negatif dan kejelekan dalam bentuk nafsu, yang senantiasa harus dikendalikan agar potensi tersebut dapat diminimalisir.

3. Al-Basyar

Kata basyar secara etimologi mengandung arti sesuatu yang indah, gembira dan baik. Dalam Al-Qur'an kata al-Basyar dijelaskan sebanyak 27 kali. $^{26}$

${ }^{24}$ Muhamad Fu'ad 'bdul Baqi, al- Mu'jam al-Mufahras li Alfazh al-Qur'an alKarim, Qahirah: Dar Hadits, hal. 153-154. hal. 159.

25 Dawam Rahardjo, Ensiklopedia Islam: Tafsir Sosial Berdasarkan KonsepKonsep Kunci, Jakarta: Paramadina, 2002, hal. 55.

${ }^{26}$ Muhamad Fu'ad 'bdul Baqi, al- Mu'jam al-Mufahras li Alfazh al-Qur'an alKarim... hal. 153-154. 
Menurut Quraish Shihab, kata basyar mengandung arti menampakkan sesuatu dengan baik dan indah. Dari kata yang serupa lahirlah kata basyarahyang berarti kulit. Manusia disebut basyarah karena kulit manusia tampak jelas dan indah berbeda dengan kulit binatang. ${ }^{27}$

Al-Basyarmengandung pengertian bahwa manusia mengalami proses reproduksi seksual dan senantiasa berupaya untuk memenuhi semua kebutuhan biologis, memiliki ruang dan waktu serta tunduk kepada hukum alamiah, baik yang berupa ketentuan Allah (takdir) maupun yang bersifat kemanusiaan (sunatullah). Isyarat manusia sebagai makhluk biologis, Allah jelaskan dalam Al-Qur'an surat Yusuf/12: 31 sebagai berikut,
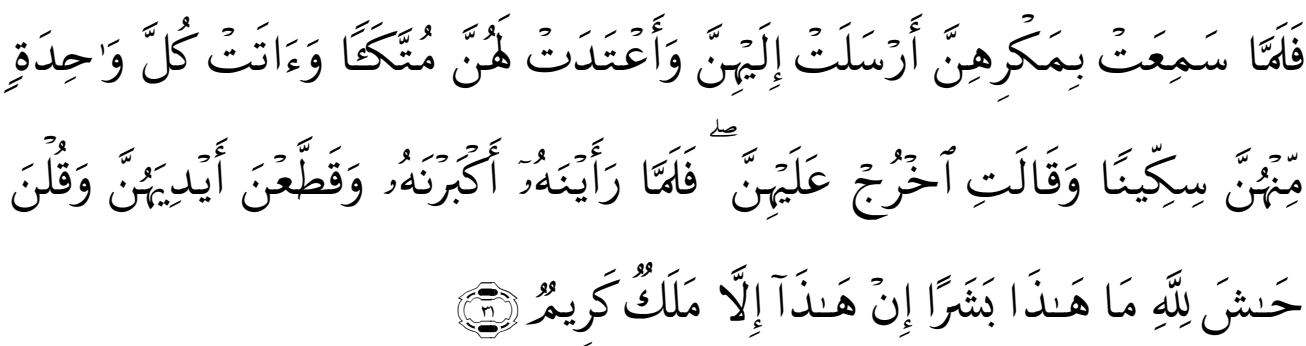

Maka tatkala wanita itu (Zulaikha) mendengar cercaan mereka, diundangnyalah wanita-wanita itu dan disediakannya bagi mereka tempat duduk, dan diberikannya kepada masing-masing mereka sebuah pisau (untuk memotong jamuan), kemudian dia berkata (kepada Yusuf): "Keluarlah (nampakkanlah dirimu) kepada mereka". Maka tatkala wanita-wanita itu melihatnya, mereka kagum kepada (keelokan rupa)nya, dan mereka melukai (jari) tangannya dan berkata: "Maha sempurna Allah, ini bukanlah manusia. Sesungguhnya ini tidak lain hanyalah malaikat yang mulia".

Ayat ini menceritakan mengenai perempuan-perempuan pembesar Mesir yang didukung Zulaikha takjub melihat ketampanan Nabi Yusuf, dalam konteks ayat ini yang dilihat adalah aspek biologis.

Untuk itu sebagai al-Basyar, Allah memberikan kekuatan dan kebebasan dengan batasan potensi yang dimiliki untuk mengelola alam semesta. Pendapat lain kata al- Basyarmerupakan pemahaman tentang manusia ditinjau dari sisi kecerdasan, memahami keberadaan diri (eksistensi), alam semesta dan Allah SWT. ${ }^{28}$ Isyarat ini dijelaskan dalam alQur'an surat Fushshilat/41: 6 sebagai berikut,

${ }^{27}$ Quraish Shihab, Wawasan al-Qur'an ... hal. 279.

28 Hamka Abdul Aziz, Pendidikan Karakter Berpusat pada Hati, hal. 28 


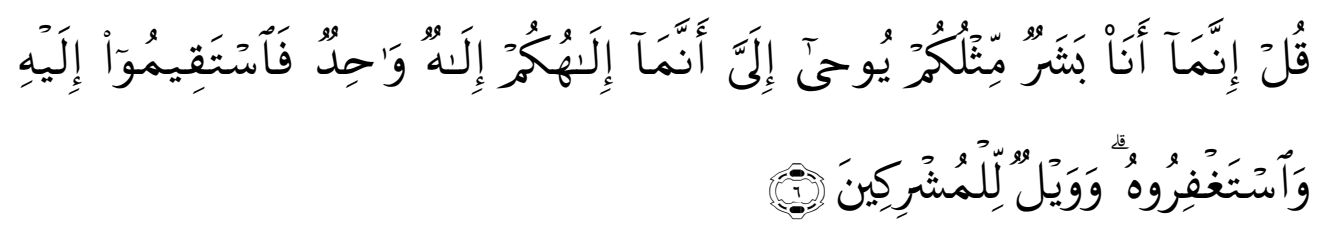

Katakanlah: "Bahwasanya aku hanyalah seorang manusia seperti kamu, diwahyukan kepadaku bahwasanya Tuhan kamu adalah Tuhan yang Maha Esa, maka tetaplah pada jalan yang lurus menuju kepada-Nya dan mohonlah ampun kepada-Nya. Dan kecelakaan besarlah bagi orang-orang yang mempersekutukan-Nya.

Jika dilihat dari ayat di atas, setiap manusia memiliki kemampuan dan kecerdasan untuk melakukan transformasi nilai yang bersifat dialogis, yang dapat saling mengisi antara satu dengan lainnya.

\section{Bani Adam}

Istilah Bani Adam merupakan sebutan dalam Al-Qur'an terhadap manusia. Bani Adam dalam Al-Qur'an mempunyai pengertian bahwa manusia beserta keturunannya mengandung pengertian basyar, insan dan an-nas. Istilah ini disebutkan dalam Al-Qur'an sebanyak 9 kali. ${ }^{29}$

Berikut ayat Al-Qur'an yang mengandung makna bani adam adalah Al-Qur'an surat yasin/36: 50sebagai berikut:

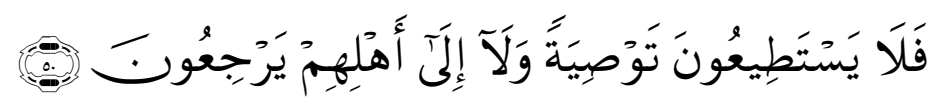

Bukankah Aku telah memerintahkan kepadamu hai Bani Adam supaya kamu tidak menyembah syaitan? Sesungguhnya syaitan itu adalah musuh yang nyata bagi kamu".

Kata Bani Adam ditekankan pada aspek amaliah manusia, dan juga pemberi arah aktifitas manusia yang dilakukan. ${ }^{30}$

Istilah Bani Adam ini merupakan kekhususan yang diberikan kepada manusia mengenai potensi akal dan potensi jasmani (fisik) serta kemampuan ilmu pengetahuan yang tidak dimiliki oleh makhluk lain selain manusia.

\section{Sejarah Teori Evolusi}

Teori evolusi mulai menjadi kajian dan perdebatan pada abad 6 SM, Diwali oleh seorang filsuf Yunani Anaximander, Empedocles, Lucretius, pendapat sama juga disampaikan oleh biologiawan Arab Al Jahiz, filsuf Persia Ibnu Miskawaih, Ikhwan As-Shafa, dan filsuf Cina Zhuangzi. hal. 1-3.

${ }^{29}$ Moh. Hasyim dan Zaki Mubarok, Akidah Islam, Yogyakarta: UII Press, 1998,

${ }^{30}$ Samsul Nizar, Filsafat Pendidikan Islam, Pendekatan Historis, Teoritis dan Praktis, Jakarta: Ciputat Press, 2002, hal. 14. 
Pendapat ini memperkirakan sejak kehidupan muncul di bumi, telah terjadi suatu proses berkesinambungan. Organisme yang hidup berasal dari bentukbentuk sebelumnya. Variasi-variasi yang besar adalah sabagai hasil respons makhluk hidup terhadap perubahan lingkungan. Respons ini berupa perubahan struktur dan fungsi tubuh makhluk individu hidup yang kemudian dilangsungkan kepada generasi selanjutnya melalui suatu proses pewarisan sifat yang telah mengalami perubahan itu. ${ }^{31}$

Teori evolusi secara biologis atau organik, telah dipelajari dan dilakukan penelitian terhadap 500 jenis binatang dan microba, oleh filsuf Yunani Aristoteles, dari hasil pengamatan tersebut terdapat perkembangan ataupun hubungan dalam jenis-jenis tersebut, meskipun hasil penelitian dan pengamatan ini masih bersifat spekulatif karena tanpa bukti secara ilmiah. Lebih rinci penelitian tersebut memberikan kesimpulan bahwa proses evolusi makhluk yang baru merupakan hasil dari bentuk percabangan dari makhlukmakhluk yang lebih tua. Manusia merupakan salah satu makhluk yang mengalami perubahan dari berbagai cabang tersebut, maka dapat digolongkan bahwa manusia berasal dari primat. ${ }^{32}$

Menurut pendapat di atas perkembangan manusia berasal dari suatu yang sederhana dan satu makhluk yang selanjutnya berkembang menjadi cabang-cabang dan manusia merupakan salah satu cabang tersebut.

Teori evolusi mengalami perkembangan, pada abad ke-18, pandangan biologis Barat yang didominasi oleh aliran esensialisme, yang meyakini mengenai pandangan bentuk-bentuk kehidupan tidak berubah. Seiring perkembangan waktu aliran esensialisme ini mulai mengalami pergeseran hal ini dipengaruhi berkembangnya faham kosmologi evolusioner dan filosofi mekanis menyebar dari ilmu fisik ke sejarah alam. Para naturalis mulai berfokus pada keanekaragaman spesies, dan mulai berkembang ilmu paleontologi dengan konsep kepunahannya lebih jauh membantah pandangan bahwa alam bersifat statis. Pada awal abad ke-19, Jean-Baptiste Lamark mengajukan teorinya mengenai transmutasi spesies. Teori ini merupakan

${ }^{31}$ Victoria Henuhili dkk, Diktat Kuliah Evolusi, Yogyakarta: Fakultas Pendidian Biologi UNY, 2012, hal. 5.

${ }^{32}$ Primata merupakan kelompok eutherian (mamalia berplasenta) tua dan beragam, dengan sekitar ratusan spesies yang hidup ditempatkan di beberapa keluarga. Sebagian besar tinggal di hutan tropis. Primata yang hidup terkecil adalah pygmy mouse lemur, yang beratnya sekitar $30 \mathrm{~g}$. Yang terbesar adalah gorila, beratnya mencapai sekitar $175 \mathrm{~kg}$. Primata adalah ordo dalam kelas mammalia yang terdiri dari prosimian, kera dan monyet. Manusia juga termasuk dalam ordo ini. 
teori evolusi pertama yang ilmiah. ${ }^{33}$ Lamarack menjelaskan bahwa dalam kehidupan dunia ini makhluk hidup tidak ada yang identik atau sama (terdapat perbedaan). Lebih lanjut Lamark menjelaskan bahwa adanya perbedaan tersebut disebabkan oleh latihan dan kebiasaan, seperti seseorang yang suka berolahraga maka badannya akan sehat, berolahraga merupakan kebiasaan dan dapat ditiru dan diturunkan kepada generasi setelahnya. Perkembangan teori evolusi selanjutnya di temukan oleh Charles Darwin. Pendapat Darwin mengenai evolusi alam adalah bahwa spesies makhluk hidup tidak diciptakan secara terpisah oleh Tuhan tetapi diciptakan berdasarkan dari nenek moyang yang sama dan menjadi berbeda satu sama lain akibat seleksi alam. Teori ini menjadikan seleksi alam sebagai pengaruh dari terjadinya dan berkembangnya makhluk hidupyang ada di dunia ini. Darwin berpendapat berdasarkan hasil pelayarannya selama 5 tahun dengan kapal H.M.S Beagle yang berangkat dari Inggris 1832, ketika singgah di kepulauan Galagapos, Darwin merasa takjub menyaksikan beragam makhluk hidup terutama variasi pada paruh burung finch. ${ }^{34}$ Seleksi alam menurut teori evolusi Darwin ini mendapat dukungan para ahli Biologi materialis dan Alfred Russel Wallace. Sampai akhir abad ke-20 teori evolusi dengan seleksi alam mengalami krisis dan keraguan, hal ini seiring dengan berkembangnya ilmu genetika yang menemukan struktur molekul DNA oleh ahli Botani dari Austria Gregor Mendelan pada tahun 1865. Pada tahun 1950 setelah ditemukan struktur gen dan kromosom menguatkan penemuan struktur molekul DNA(Deoxyribonucleic Acid) yang berisi informasi genetik meragukan teori evolusi seleksi alamnya Charles Darwin dengan alasan kerumitan yang luar biasa dari kehidupan untuk berubah menjadi species baru dan ketidakabsahan mekanisme evolusi yang diajukan Charles Darwin. $^{35}$

Teori Darwin tidak dapat menjelaskan mengenai evolusi universal, dengan perkembangan teknologi dan ilmu genetik tersebut melalui mikroskop yang lebih canggih telah ditemukan organisme awal dengan kromosomnya. Dalam kromosom tersebut dapat ditemukan gen-gen yang menjadi penerus ciri-ciri yang diturunkan orang tua kepada anak dimana

\footnotetext{
${ }^{33}$ http://www.perpusku.com/2017/01/teori-evolusi-pengertian-sejarah-dan-tokohpencetusnya.html, diakses pada tanggal, 14 Februari pukul. 18.05.

${ }^{34}$ Pandangan dan hasil penelitiannya ia tulis dan publikasikan dalam buku The Origin of Species by Means of Natural Selection pada tahun 1859. Namun dalam teori evolusinya Darwin mengalami masalah dan kesulitan sehingga ia tulis dalam satu bab buku tersebut dengan judul Difficulties of the Theory. Cartono, Teori Evolusi, Bandung: Prima Press, 2008, hal. 4

${ }^{35}$ Cartono, Teori Evolusi, Bandung: Prima Press, 2008, hal. 4.
} 
kromosom dalam sel manusia ada 46 tersebut berasal dari ayah 23 dan ibu 23, dari hasil sel manusia dan kromosom ini dapat disimpulkan bahwa biji gandum tetap dihasilkan dari biji gandum, dan dari manusia tetap lahir manusia. ${ }^{36}$

Dalam analisis genetika gen-gen dalam kromosom manusia lebih dekat dengan kentang yang memiliki kromosom 46, sedangkan pada simpanse terdapat 48 kromosom, akan tetapi pembuktian homologi yang berkaitan dengan kromosom dan gen tidak dapat dijadikan acuan dan bukti kuat telah terjadinya evolusi. Hal ini membantah teori Carles Darwin yang menjelaskan bahwa semua spesies berasal dari satu spesies yang sama.

Selain ditemukannya struktur DNA(Deoxyribonucleic Acid) dengan pembuktian kromosom dan gen, catatan fosil dapat dijadikan salah satu rujukan mengenai perjalanan teori evolusi ini. ${ }^{37}$ Dalam catatan fosil dijelaskan bahwa makhluk hidup yang ditemukan pada lapisan bumi periode Kambrium hidup dan muncul dengan tiba-tiba tidak ada nenek moyang yang hidup sebelumnya. Fosil-fosil tersebut berasal dari siput trilobite, bunga karang, cacing tanah, ubur-ubur, landak dan inventebrata lainnya, terjadinya kehidupan ini menjadi kejadian ajaib yang disebut ledakan Kambrium. Ledakan Kambrium ini mengisyaratkan bukti kuat adanya penciptaan terhadap makhluk hidup ini dan melemahkan teori evolusiCharles Darwin.

Dari berbagai pandangan dan pendapat mengenai teori evolusi di atas dapat dijelaskan bahwa teori evolusi tentang makhluk hidup yang berkembang sejak abad 6 SM mengalami perkembangan pesat dan kontadiktif ketika Charles Darwin menemukan teori evolusi yang menjelaskan bahwa Pendapat Darwin mengenai evolusi alam adalah bahwa spesies makhluk hidup tidak diciptakan secara terpisah oleh Tuhan tetapi diciptakan berdasarkan dari nenek moyang yang sama dan menjadi berbeda satu sama lain akibat seleksi alam.

36 Adelbert Snijders, Antropologi Filsafat Manusia Paradoks dan Seruan, Yogyakarta: Kanisius, 2004, hal.177.

37 Dalam catatan fosil telah ditemukan keganjilan mengenai penemuan tulang rahang dan fragmen tengkrak oleh seorang dokter dan ahli Paleontologi di Piltdown Inggris pada tahun 1912, bernama Charles Dawson yang menjelaskan tulang rahang tersebut lebih mirip kera akan tetapi bentuk gigi dan tengkorak lebih mirip manusia, penemuan tersebut terbantahkan oleh penelitian fluorin yang dilakukan oleh Kenneth Oakley dari Departemen Paleontologi British, hasil penelitian tersebut menunjukkan bahwa tengkorak tersebut berasal dari manusia 500 tahun yang lalu dan tulang rahang adalah kepunyaan kera yang baru saja mati, gigi disusun berderet dan ditambahkan pada rahangnya dan sendinya dirancang untuk menyerupai manusia. Hal ini membuktikan telah terjadi pemalsuan fosil oleh Charles Dawson dan pemalsuan tersebut diumumkan pada tahun 1953 oleh Weiner. Cartono, Teori Evolusi, Bandung: Prima Press, 2008, hal. 196-200. 
Dari penjelasan di atas tentang teori evousi dapat dijelaskan bahwa, teori evousi tidak hanya berhubungan dengan manusia akan tetapi berkaitan dengan makhluk hidup lainnya di alam raya ini. Selanjutnya teori evolusi tentang seleksi alam yang ditemukan Charles Darwin merupakan salah satu teori evolusi yang berkembang.Terdapat perbedaan antara teori evolusi dengan teori evolusi seleksi alam Darwin. Teori evolusi menjelaskan bahwa kehidupan berasal dari yang sederhana dan mengalami proses perubahan yang memiliki bermacam-macam fungsi dan kemampuannya, sedangkan teori evolusi Darwin menjelaskan bahwa suatu jenis makhluk hidup dapat muncul dari jenis yang lain dan berasal dari nenek moyang dan tidak diciptakan. Untuk lebih memperkaya khasanah keilmuan mengenai teori evolusi akan dijelaskan dari perspektif Al-Qur'an khususnya teori evolusi manusia.

\section{Teori Evolusi Manusia dalam Al-Qur'an}

Teori evolusi dalam Al-Qur'an merupakan rangkaian kehidupan manusia yang Allah jelaskan dalam beberapa ayat dengan penjelasan penciptaan manusia mulai dari tanah, air dan sperma, rangkaian evolusi dalam Al-Qur'an menghadirkan Allah SWT sebagai pencipta manusia dan makhluk hidup. Proses penciptaan manusia yang dapat dijadikan pendekatan teori evolusi Allah SWT isyaratkan dalam satu ayat secara lengkap yaitu AlQur'an Surat al-Hajj/ 22: 5:
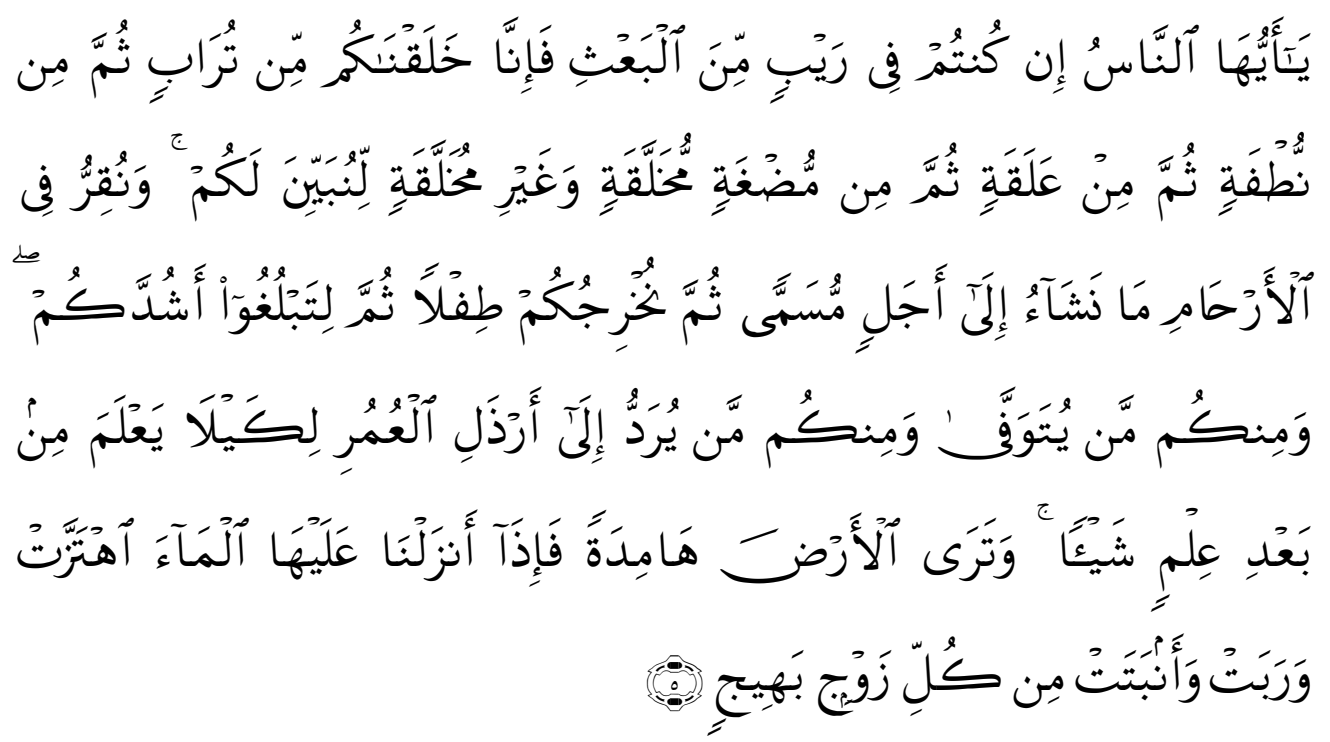

Hai manusia, jika kamu dalam keraguan tentang kebangkitan (dari kubur), maka (ketahuilah) sesungguhnya Kami telah menjadikan kamu dari tanah, 
kemudian dari setetes mani, kemudian dari segumpal darah, kemudian dari segumpal daging yang sempurna kejadiannya dan yang tidak sempurna, agar Kami jelaskan kepada kamu dan Kami tetapkan dalam rahim, apa yang Kami kehendaki sampai waktu yang sudah ditentukan, kemudian Kami keluarkan kamu sebagai bayi, kemudian (dengan berangsur-angsur) kamu sampailah kepada kedewasaan, dan di antara kamu ada yang diwafatkan dan (adapula) di antara kamu yang dipanjangkan umurnya sampai pikun, supaya dia tidak mengetahui lagi sesuatupun yang dahulunya telah diketahuinya. Dan kamu lihat bumi ini kering, kemudian apabila telah Kami turunkan air di atasnya, hiduplah bumi itu dan suburlah dan menumbuhkan berbagai macam tumbuh-tumbuhan yang indah.

Proses penciptaan manusia dalam ayat tersebut Allah jelaskan melalui dua bagian, pertama, proses penciptaan dari tanah yaitu Nabi Adam dan kedua, proses penciptaan manusia setelah adam yaitu melalui proses dalam Rahim (kandungan). Ayat ini juga mengisyaratkan tentang penciptaan manusia dari mulai diciptakan (ditiupkan dalam rahim), proses dewasa, masa tua dan sebagian Allah wafatkan sebelum masa dewasa dan tua sampai Allah jelaskan bagaimana manusia setelah tua akan kembali lagi ke masa kanakkanak dan mengalami pikun hingga akhirnya kembali ke tanah sebagaimana penciptaan pertama manusia.

Kata thurabsecara bahasa bermakna tanah gemuk, maksud tanah gemuk menurut al-Ishfahani adalah tanah yang berada dalam lapisan pertama yang berwarna hitam. Kata thurab dalam Al-Qur'an disebutkan sebanyak 22 kali. ${ }^{38}$ Ar-Razi menjelaskan bahwa jenis-jenis tanah yang terkandung dalam unsur tersebut satu sama lin tidak bertentangan. Hal ini disesuaikan dengan jenis pencitaan pertama yaitu diawali dengan thurab (debu) kemudian menjadi thin (tanah), selanjutnya menjadi lumpur, kemudian seperti tembikar. ${ }^{39}$

Tanah merupakan unsur terpenting yang melengkapi susunan tubuh manusia. Dari unsur tanah ini, proses penciptaan berlanjut tahap demi tahap dalam bentuk komposisi kimiawi yang sangat diperlukan untuk menyususn tubuh manusia. Susunan tubuh manusia berdasarkan biokimia tersusun dari karbohidrat, lemak dan protein. Dengan melalui proses kimia akan membentuk gugusan atom (molekul) penyususn tubuh. Unsur-unsur tersebut yaitu Karbonat (CO3, pen.), Oksigen (O2), Hidrogen (H2), Pospor (P), Kibrit, Azur, Kalsium (Ca), Votasium, Sodium, Magnesium (Mg), Besi (Fe),

${ }^{38}$ Al-Ragib al-Ishfahani, Mu'jam Mufradat al-Alfazh al-Qur'an, Beirut: Daral-Fikr , T, Th, hal. 323.

${ }^{39}$ Fakhr al-Razi. Al-Tafsir al-Kabir, Beirut: Dâr al-Hayâ al-Turâts al-‘Arabia, 1990, jilid Vlll, hal. 137. 
Tembaga (Cu), Yodium (Y), Florit, Kobait (Co), Seng (Zn), Silikon (Si), dan Alumunium (Al).7 Unsur-unsur tersebut melalui proses rantai makanan terserap ke dalam tubuh melalui tumbuh-tumbuhan, hewan, dan air. Melalui proses kimiawi, unsur-unsur dalam tubuh manusia tersebut berubah menjadi darah, daging, dan air mani. ${ }^{40}$

Beragam kandungan unsur yang bermanfaat terdapat dalam tanah yang menjadi unsur penting dalam penciptaan manusia. kandungan unsur tersebut mengisyaratkan bahwa manusia diciptakan sebagai makhluk istimewa dan berguna.

Kandungan selanjutnya adalah nuthfah(sperma). Sperma merupakan bagian dari dari air mani yang tersusun juga dari campuran zat-zat lain, seperti zat gula yang diperlukan untuk menyediakan energy bagi sperma, menetralkan asam di pintu masuk Rahim dan melicinkan sekitarnya agar memudahkan perputaran sperma. Dari hasil penelitian terbaru dijelaskan bahwa pria akan mengeluarkan sperma sekitar 200-500 juta dan dari sekian banyak jumlah tersebut yang akan diterima indung telur hanya satu, karena ketika air mani keluar jumlah sperma hanya $10 \%$, selebihnya adalah zat enzim, vitamin c, kalsium, protein, sodium, zat besi, zat asam seta fruktosa gula. ${ }^{41}$

Nasaruddin Umar berdasarkan berbagai sumber rujukan menjelaskan bahwa substansi manusia terdapat 12 istilah yaitu, air, tanah, tanah gemuk, tanah lempung, tanah lempung yang pekat, tanah lempung seperti tembikar, tanah lempung dari lumpur, dari diri yang satu, sari pati lempung, air mani yang ditumpahkan, cairan mani yang bercampur, dan cairan yang hina. ${ }^{42}$

Penafsiran ayat di atas menjelaskan tentang proses penciptaan manusia sebagai kelanjutan dari Adam yang diciptakan melalui fungsi reproduksi dengan melibatkan suami dan istri yang Allah beri kekuatan untuk mengandung bagi perempuan dan laki-laki memberikan cairan dalam bentuk sperma sebagai cikal bakal anak.

\footnotetext{
${ }^{40}$ Abd al Razziq Nawfal, Allah dari Segi Ilmu Pengetahuan Modern, Surabaya: Bina Ilmu, 1983, hal. 149.

${ }^{41}$ Adapun kandungan sperma terdiri dari ammonia, ascorbic acid, ash, calcium, carbon dioxide, chloride, cholesterol, citrid acid, creatine ergothioneine, fructose, glutathione, gycerylphorylcholine, inositol, lactid acid, magnesium, nitrogen non protein, phosphorus, acid soluble, inorganic, lipid, phosphorylcholine, total (lipid), potassium, pyruvic acid, sodium, sorbitol, vitamin B 12, sulfur, urea, uric acid, zinc, copper Muhammad Abdul Jawad, Menyingkap Fakta Baru dan MIsteri Kehidupan Manusia, Jakarta: AMP Press, 2014, hal. 20-21.

${ }^{42}$ Nasaruddin Umar, Agumen Kesetaraan Gender Perspektif Al-Qur'an, Jakarta: Paramadina, 2010, cet-2, hal.202-204.
} 
Selanjutnya proses penciptaan manusia terdapat dalam Al-Qur'an surat an-Nisa/4: 1 :

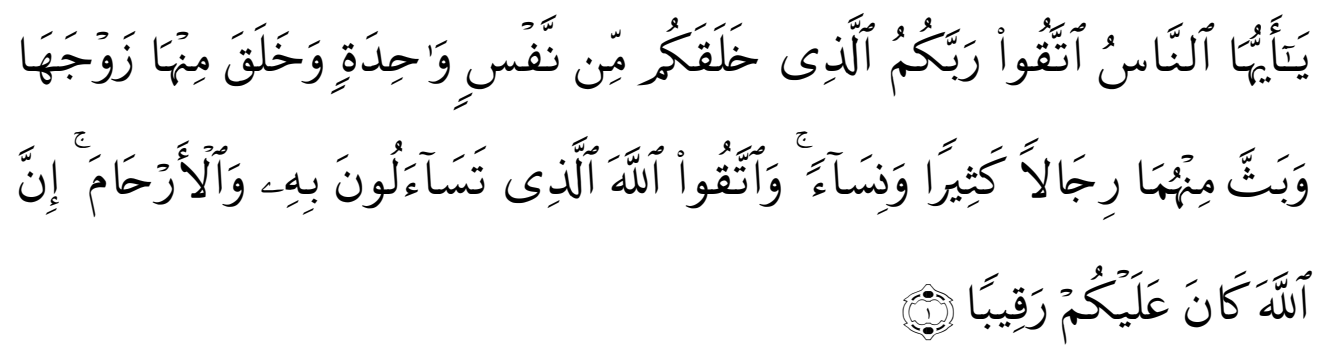

Hai sekalian manusia, bertakwalah kepada Tuhan-mu yang telah menciptakan kamu dari seorang diri, dan dari padanya Allah menciptakan isterinya; dan dari pada keduanya Allah memperkembang biakkan laki-laki dan perempuan yang banyak. Dan bertakwalah kepada Allah yang dengan (mempergunakan) nama-Nya kamu saling meminta satu sama lain, dan (peliharalah) hubungan silaturrahim. Sesungguhnya Allah selalu menjaga dan mengawasi kamu.

Menurut Sayyid Qutub dalam Tafsir Fi Zhilalil Qur'anSurat An-Nisa ayat 1 ini dimulai dengan menjelaskan manusia sebagai makhluk ciptaan Allah SWT. Manusia berasal dari ketentuan Allah yang berhubungan dalam satu Rahim, bertemu dalam satu koneksi dan bersumber dari satu asal-usul dan bernasab kepada satu nasab, hal ini merupakan upaya pembelajaran untuk selalu memegang cinta kasih (kekeluargaan), memelihara hak masingmasing individu, dan memegang teguh hubungan rububiyyah. Ayat ini menjelaskan bahwa dasar kehidupan adalah keluarga, dimana Allah SWT menciptkan laki-laki sebagai suami dan diciptakan perempuan sebagai isteri untuk saling melengkapi sehingga dengan keduanya Allah mengembang biakan menjadi banyak. Dari tatanan kelaurga terbentuklah sistem masyarakat, untuk itu landasan kelaurga ini harus dikuatkan yaitu menjalankan kehidupan sesuai fitrah, dan memposisikan manusia baik itu laki-laki maupun perempuan sesuai kodrat, serta saling melengkapi dan mengisi dalam membangun keutuhan keluarga. ${ }^{43}$

Sedangkan Abu Muslim Al- Isfahani menafsirkan kata مِنَهَ dalam ayat tersebut dengan arti dari jenis bahan yang sama yakni tanah, dengan

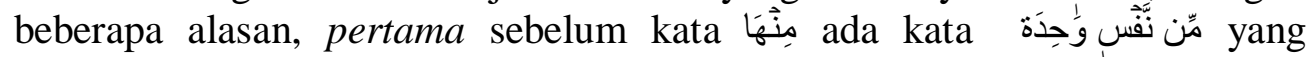
maknanya dari diri yang satu ini menunjukan kesetaraan dan kesejajaran, kedua, penafsiran hadits dari tulang rusuk Adam berdasarkan hadis yang dalam teks aslinya tidak ada kata Adam, ketiga tulang rusuk (dil'un) tidak

${ }^{43}$ Sayyid Quthb, Tafsir Fi Zhilalil Qur'an (Di Bawah Naungan Al-Qur'an), As'ad Yasin dkk (penerjemah), Jakarta: Gema Insani Press, 2001, hal. 269-272. 
terdapat dalam surat annisa 1 bagaimana menjadi marji ( tempat kembali dhamir haa pada minhâ) keempat, penafsiran jumhur tidak sesuai dengan alQuran yang tujuan pokoknya untuk menjunjung derajat perempuan. ${ }^{44}$

Dari penafsiran ayat tersebut di atas menjelaskan bahwa penciptaan manusia dalam surat an-Nisa/4: 1 tidak hanya penciptaan Adam akan tetapi penciptaan Hawa sebagai isteri yang bertujuan untuk membentuk keluarga dalam satu ikatan dan saling melengkapi sehingga dari keduanya menghasilkan anak-anak keturunan yang tersebar di bumi yang bertujuan untuk beribadah kepada Allah SWT dan menggunakan alam ini dengan baik, serta melalui proses evolusi dalam Al-Qur'an dapat diambil hikmah bahwa proses penciptaan manusia dalam Al-Qur'an begitu terinci, sistematis dan mengandung sains yang dapat dijadikan landasan dalam perkembangan ilmu pengetahuan.

\section{Kesimpulan}

Evolusi yang terjadi di bumi ini terjadi secara keseluruhan, baik itu tumbuhan, binatang dan manusia. Al-Qur'an menjunjung tinggi ilmu pengetahuan dan sains berbagai kandungan Al-Qur'an mengisyaratkan mengenai evolusi diantaranya proses penciptaan manusia, proses penciptaan langit dan bumi dalam enam masa dan teori big bang. Perbedaan teori evolusi dengan teori evolusi yang berkembang di Barat terutama teori evolusi Charles Darwin terletak pada keyakinan bahwa seluruh makhluk yang ada dan hidup di bumi ini adalah diciptakan, dan Allah SWT sebagai penciptanya. Selain itu terdapat perbedaan pandangan antara teori evolusi Barat dan Al-Qur'an, teori evolusi Barat khususnya teori Darwin menjelaskan bahwa manusia tercipta dan berasal dari induk yang sama dengan makhluk lain, hal ini adalah titik perbedaannya, dimana Al-Qur'an menjelaskan bahwa manusia Allah ciptakan dan berasal dari ketrunan Nabi Adam, yang Alah SWT telah siapkan untuk menjadi khalifah fi al-Ardh.

44 Ibrahim hosein, Ahmad Munif Duratma Putra, Al-Quran dan Peranan Perempuan dalam Islam, Jakarta: IIQ, 2007, hal. 41-42 


\section{DAFTAR PUSTAKA}

Abidin, Zainal. Filsafat Manusia, Bandung: Rosdakarya, 2006.

Achmadi Susanto. A, Filsafat Ilmu: Suatu Kajian dalam Dimensi Ontologis, Epistimologis, dan Aksiologis, Jakarta: Bumi Aksara

Al-Imam Abu al-Qasim Jarullah Mahmud bin 'Umar al-Zamakhsyari, alKasysyaf 'an Haqaiq al-Tanzil wa al-'Uyun al-Aqawil fi wujuh alTa'wil, Beirut : Dar al-Kitabal-'Arabi, tth.

Arifin, Chairul, Filsafat Ilmu Pengetahuan, Jakarta: ISTN, 1998

Asmoro, Filsafat Umum, Jakarta: PT. Raja Grafindo Persada, 1995

Bakhtiar Amsal, Filsafat Ilmu, Jakarta: PT. Raja Grafindo

Baqi, Muhamad Fu'ad 'bdul. al-Mu'jam al-Mufahras li Alfazh al-Qur'an al-Karim, Qahirah: Dar Hadits, hal. 153-154.

Cartono, Teori Evolusi: Mengungkap Rahasia Evolusi Makhluk Hidup, Bandung: Prisma Press, 2008.

Darsono, Tjatjuk Siswandoko. Manajemen Sumber Daya Manusia abad 21, Jakarta: Nusantara Consulting, 2011.

Durant, Will. The Story of Philosophy, New York: Garden City Publ. Co. Inc, 1927.

Gaarder Jostien, Dunia Sophie (Sebuah Novel Filsafat): Bandung, 2014, Hakim, Usman A. Kamus Bahasa Indonesia, Jakarta: Balai Pustaka, 2001

Hude, Darwis. Logika Al-Qur'an, Jakarta:Eurobia, 2013.

Ibrahim M. Subhi, Asas-Asas Filsafat, Jakarta: Lecture, 2013.

Jalaluddin, Filsafat Ilmu Pengetahuan, Jakarta: Raja Grafindo Persada, 2013

Jawad, Muhammad Abdul. Menyingkap Baru dan Misteri Kehidupan Manusia, Jakarta: AMP Press, 2014.

Koestenbaum, Peter. Philosophy: General Introduction, New York: American Book Campany, 1968.

Madjid,Abdul Latief.Evaluasi Kinerja SDM: Konsep Aplikasi, Standard an Penelitian, Jakarta: Haja Mandiri, 2014.

Nawawi,Hadari Mimi Martini, Manusia Berkualitas, Yogyakarta: Gajah Mada University Press, 1994.

Nuh,Abdullah bin. Kamus Indonesia Arab, Jakarta: Mutiara, 2008

Prawironegoro Darsono, Filsafat Ilmu, Jakarta: Nusantara Consulting, 2010

Rahardjo,Dawam Ensiklopedia Islam: Tafsir Sosial Berdasarkan KonsepKonsep Kunci, Jakarta: Paramadina, 2002. 
Russel, Betrand. A history of Western Philosophy, London: Feffer \& Simons Inc, 1947.

Pascasarjana PTIQ, Panduan Penyusunan Tesis dan Disertasi, Jakarta: Pascasarjana PTIQ, 2017

Saebani Ahmad Beni, Filsafat Ilmu, Bandung: Pustaka Setia, 2009

Setiadi, Andi, Rahasia Cara Belajar Einstein, Yogyakarta: Diva Press, 2014

Sidharta B. Arif, Apakah Filsafat dan Filsafat ilmu itu? Bandung: Pustaka Sutra, 2008

Shihab, Quraish. Wawasa Al-Qur'an Tafsir Maudu'I atas Berbagai Persoalan Umat, Bandung: Mizan, 1998.

Snijders, Alberts. Antropologi Filsafat Manusia Paradoks dan Seruan, Yogyakarta: Kanisius, 2004.

Soebagio Mas, Supriatna Slamet, Dasar-dasar Filsafat Suatu Pengantar Ke Filsafat Hukum, Jakarta: Akademika Presindo

Suharto,Dedhi Qur'anic Intelligence Quotient (membangun kecerdasan AlQur'an), Tangerang: FBA Press.

Suriasumantri, S. Jujun, Filsafat Ilmu: Sebuah Pengantar Populer, Jakarta: CV. Muliasari, 2001, cet ke-14.

Syradika Agus, Virgana, Filsafat Ilmu, Tangerang: Pustaka Mandiri, 2012.

Umar,Nasaruddin. ArgumenKesetaraan Gender Perspektif Al-Qur'an, Jakarta: Paramadina, 2001.

Umiarso, Zamroni. Pendidikan Pembebasan Dalam Perspektif Barat dan Timur, Jakarta : Ar-Ruz Media, 2011.

Watloly, Aholiab, Tanggung Jawab Pengetahuan, Yogyakarta: Kanisius, 2001

Qurthubi, Syaikh Imam. Tafsir Al-Qurtubi Akhmad Khatib, Jakarta : Pustaka Azzam, 2009.

Loye, David. Introduction: Toward a Fully Human Theory of Evolution, The Journal of New Paradigm Research, vol.58 issue 2-3, 2010.

Darwin and the Fully Human Theory of Evolution, The Journal of New Paradigm Research, vol.58 issue 2-3, 2010. 